\title{
Impact of 20:4n-6 supplementation on the fatty acid composition and hemocyte parameters of the Pacific Oyster Crassostrea gigas.
}

\author{
Maryse Delaporte ${ }^{\mathrm{a}^{*}}$, Philippe Soudant ${ }^{\mathrm{b}}{ }^{\star}$, Jeanne Moal $^{\mathrm{a}}$, Emilie Giudicelli ${ }^{\mathrm{a}}$, Christophe Lambert ${ }^{\mathrm{b}}$, \\ Catherine Séguineau ${ }^{a} \&$ Jean-François Samain ${ }^{a}$
}

\footnotetext{
${ }^{a}$ UMR 100 Physiologie and Ecophysiologie des Mollusques Marins, centre IFREMER de Brest, BP70, 29280 Plouzané, France

b Laboratoire des Sciences de l'Environnement Marin, UMR 6539, Institut Universitaire Européen de la Mer, Université de Bretagne Occidentale, Technopôle Brest-Iroise, 29280 Plouzané, France
}

*: Corresponding author : Philippe.Soudant@univ-brest.fr

\begin{abstract}
Arachidonic acid (20:4n-6, ArA) and its eicosanoid metabolites have been demonstrated to be implicated in immune functions of vertebrates, fish, and insects. Thus, the aim of this study was to assess the impact of ArA supplementation on the FA composition and hemocyte parameters of oysters Crassostrea gigas. Oyster dietary conditioning consisted of direct addition of ArA solutions at a dose of $0,0.25$, or $0.41 \mathrm{mg} \mathrm{ArA} \mathrm{per} \mathrm{mL}$ of seawater into tanks in the presence or absence of T-Iso algae. Results showed significant incorporation of ArA into gill polar lipids when administered with algae (up to 19.7\%) or without algae (up to 12.1\%). ArA supplementation led to an increase in hemocyte numbers, phagocytosis, and production of reactive oxygen species by hemocytes from ArAsupplemented oysters. Moreover, the inhibitory effect of Vibrio aestuarianus extracellular products on the adhesive proprieties of hemocytes was lessened in oysters fed ArA-supplemented T-Iso. All changes in oyster hemocyte parameters reported in the present study suggest that ArA and/or eicosanoid metabolites affect oyster hemocyte functions
\end{abstract}

Keywords: Crassostrea gigas, Bivalve, Nutrition, Poly-unsaturated fatty acids, Arachidonic Acid, Oyster immunity, Hemocyte parameters 


\section{Introduction}

The dietary impact of long chain n-3 and n-6 essential polyunsaturated fatty acids (PUFAs) have been extensively studied in human medical research, including the modulation of the human immune system. Thus, long chain n-3 PUFAs has been shown to have antiinflammatory and immunomodulatory properties for a number of immune functions including phagocytosis, reactive oxygen species production, and lymphocyte proliferation $[1,2]$. The impact of dietary long chain n-6 PUFAs on immunity however has been less well investigated and is still controversial with both pro-inflammatory and immunosuppressive properties having been associated with these molecules [2]. In vitro studies have focused on the mechanisms by which n-6 PUFAs especially arachidonic acid (20:4n-6, ArA) and its eicosanoid metabolites can affect immune functions [3-8]. These studies demonstrated that ArA, generally found in high amount in membranes of higher vertebrates (human, rat), likely via its eicosanoid metabolites can influence phagocytosis, NADPH oxidase activation, actin polymerisation and $\mathrm{Ca}^{+}$release.

Similar studies on fish nutrition have evaluated the impact of n-3 and n-6 dietary PUFAs on immune functions [9-15]. Thus, Lin and Shiau [13] demonstrated that lipid supplemented diets resulted in increased numbers of white blood cells and enhances phagocytosis and the generation of reactive oxygen species in grouper Epeniphelus malabarcius when compared to fish fed lipid poor diets. Wu et al. [15] investigated more specifically the effect of long chain n-3 PUFAs (20:5n-3 (EPA) and 22:6n-3 (DHA)) on the immune functions of the grouper Epinephelus malabarcius. The authors reported that DHA enhanced phagocytic function and T-cell proliferation and was superior to EPA in influencing the cellular defence responses of the grouper. Moreover, eicosanoid metabolites derived from ArA PUFA are also significant in fish immunity. Tafalla et al. [16] demonstrated that $\mathrm{LTB}_{4}$ in leukocyte-derived supernatants have an anti-viral activity against viral hemorrhagic septicemia virus in the turbot Scophthalamus maximus. However, the authors did not exclude the involvement of other factors as $\mathrm{PGE}_{2}$.

In bivalves, for more than two decades, studies have focused on the determination of the nutritional values of various algal species to support and improve larval development, growth, and metamorphosis under hatchery conditions [17-23]. Fewer studies have investigated the impact of nutrition on immune responses of bivalves [24-26]. Thus recently, Delaporte et al. [26] have demonstrated that feeding Pacific oysters Crassostrea gigas and Manila clams Ruditapes philippinarum with cultures of the microalga Chaetoceros calcitrans (a diatom) led to increases in hemocyte numbers, phagocytosis and reactive oxygen species production. These authors suggested that the fatty acid composition of Chaetoceros calcitrans, characterised by high proportion of EPA (17.8\%) and ArA (2.0\%), may be responsible for the changes observed in immune responses of both species, as demonstrated for vertebrates and fishes fed on different oils. Similarly, Hégaret et al. [24] showed that immune parameters of the Eastern oyster Crassostrea virginica were modulated by the quality of the algal diet. Nonetheless, no specific PUFA could be clearly identified as responsible for those changes. Lastly, dietary conditioning using lipid emulsion was used to assess the impact of EPA on hemocyte parameters of the oyster C. gigas [25]. In this study, a decrease of phagocytosis and reactive oxygen species production was temporarily observed for oyster fed the highest dose of EPA. These results suggested that this PUFA may have an impact on hemocyte function, but unfortunately without excluding a concomitant impact of ArA since the lipid emulsion also contained a significant amount of ArA.

The aim of this current study was to specifically determine the impact of dietary ArA on hemocyte parameters of $C$. gigas. To do this, a new supplementation method developed by 
Séguineau et al. [27] based on the direct addition of individual PUFA along with T-Iso algae (deficient in ArA) was used.

\section{Materials and Methods}

\section{Oyster dietary treatments}

One year old oysters, C. gigas (Thunberg 1793), produced in 2003 at the IFREMER hatchery in La Tremblade (Charente, France), were conditioned in May 2004 at the IFREMER shellfish laboratory in Argenton (Finistère, France) in 50-L tanks. Oysters were acclimated to the experimental temperature of $17^{\circ} \mathrm{C}$ for two weeks prior to the dietary experiment. After the acclimation period, oysters were divided randomly and distributed into 9 tanks (70 oysters per tanks, 3 replicates per treatment) filled with $45 \mathrm{~L}$ of $20 \mu \mathrm{m}$ filtered seawater, mixed and aerated using an immersed pump. Thereafter, oysters were fed Isochrysis sp., clone T-Iso, supplemented with ArA solution for 4 weeks. T-Iso was chosen for this experiment because of its low concentration in arachidonic acid $(0.1 \%$, [26]). The daily algal ration was established at $4 \%$ algal dry weight per oyster dry weight. A peristaltic pump was adjusted to distribute the algae ration over a 18 hours period per day. ArA (Sigma A-9376) was dissolved in ethanol at the concentration of $10 \mathrm{mg} \mathrm{mL} \mathrm{m}^{-1}$ according to the procedure of Séguineau et al. [27]. This ArA solution was further diluted in ethanol to allow addition of a same volume of ethanol per tank and to obtain the following final concentrations: $0 \mu \mathrm{g}$ (control ethanol solution), $0.25 \mu \mathrm{g}$, or $0.41 \mu \mathrm{g}$ of ArA per $\mathrm{mL}$ of sea water. ArA solutions were added twice a day (half dose in the morning and half dose in the evening in order to avoid ArA oxidation). Tanks and oysters were daily cleaned. Every two weeks, 15 oysters were sampled for biochemical analyses and 20 oysters for immune analyses. After the first sampling, volume of seawater per tank was adjusted in order to maintain a stable effective volume per oyster during the experiment. No mortalities were recorded over the whole experiment.

One month later, a separate control experiment was conducted for a period of 2 weeks with the same experimental protocol to assess the assimilation of dissolved ArA without algal supply in oysters from the same origin.

\section{Condition index and biochemical composition}

At each sampling date, whole oyster, shell, and wet flesh weights were measured on 15 oysters. The condition index of oysters was calculated, as described by Walne and Mann [28], following the formula: dry flesh weight / dry shell weight X 1000. Thereafter, three pools constituted by the wet flesh tissues of five animals were generated. Pools were frozen in liquid nitrogen $\left(-196^{\circ} \mathrm{C}\right)$ and treated as described in Delaporte et al. [29]. Total lipid content was estimated according to Bligh and Dyer [30] and carbohydrate and protein contents were measured colorimetrically following the procedures of Dubois et al. [31] and Lowry et al. [32], respectively. Results are expressed as mg of carbohydrate, lipids and protein per mg of oyster dry flesh weight. 


\section{Fatty acid analysis of oyster gills}

\section{Sampling and extraction}

Gills were dissected from the same animals utilised for the hemocyte-parameter analyses. Three pools of gills from 5 animals were constituted and frozen in liquid nitrogen at $196^{\circ} \mathrm{C}$. Pooled gill samples were ground with a Dangoumeau homogeniser, and $300 \mathrm{mg}$ of the ground tissue was transferred to a tube containing $6 \mathrm{ml}$ of chloroform-methanol mixture (2:1, by vol). After centrifugation, the lipid extract was transferred to a clean tube, sealed under nitrogen, and stored at $-20^{\circ} \mathrm{C}$.

\section{Separation of polar and neutral lipid}

Neutral and polar lipids of gill lipid extracts were purified on a Silica gel micro-column according to Marty et al. [33] and analysed as described in Delaporte et al. [29]. Briefly, an aliquot of the lipid extract in chloroform/methanol was evaporated to dryness. Then, lipids were re-dissolved in a chloroform-methanol mixture (98:2, v:v) and placed on a silica gel microcolumn [30x5 mm i.d. Kieselgel, 70-230 mesh (Merck) previously heated to $450^{\circ} \mathrm{C}$ and deactivated with $5 \mathrm{wt} \%$ water]. Neutral lipids were eluted with a chloroform-methanol mixture (98:2, v:v), and the polar lipids were eluted separately with methanol. After transesterification of the neutral and polar lipid extracts from gills by $10 \% \mathrm{w}: \mathrm{w}$ boron trifluoride/methanol (Metcalfe and Schmitz, 1961), fatty acid methyl esters (FAME) were analysed in a gas chromatograph equipped with an on-column injector, a DB-Wax (30 m x $0.25 \mathrm{~mm}, 0.25 \mu \mathrm{m}$ film thickness) capillary column, and a flame ionization detector. Hydrogen was used as the carrier gas. The fatty acids were identified by comparing their retention times with those of standards and confirmed by gas liquid chromatograph-mass spectrometry (GC-MS).

Fatty acid composition of gills was expressed as weight percentage of the total fatty acids of each lipid fraction. Total fatty acid content (neutral + polar lipids) per gill sample was expressed as $\mu \mathrm{g}$ of FAs per mg of gill wet weight.

As polar lipids generally provide a good approximation of cell membrane lipids and are the dominant lipids in hemocyte and gill tissues [26, 29, 34], only fatty acid composition values of the polar lipid fraction of gill lipid extracts were presented in this study to simplify the presentation of fatty acid data.

\section{Measurements of immunological parameters by flow cytometry}

Measurements of hemocyte types, numbers, and functions were performed on a FACScalibur flow cytometer (B-D Biosciences, San Jose, CA, USA) equipped with a 488 $\mathrm{nm}$ argon laser. Hemolymph sampling and hemocyte parameter measurements are described below. For each assay, samples were filtered through a $80 \mu \mathrm{m}$ mesh prior to flow cytometer analysis in order to eliminate large debris $(>80 \mu \mathrm{m})$.

\section{Hemolymph sampling}

Hemolymph was withdrawn from individual oysters using a $1 \mathrm{~mL}$ plastic syringe fitted with a 25-gauge needle via a notch adjacent to the adductor muscle created just prior the bleeding. All hemolymph samples were examined microscopically for contamination (e.g., oocytes, sperm, algae) and stored individually in micro-tubes at $0{ }^{\circ} \mathrm{C}$. Three pools of five individual samples were used for the following immunological assays. 


\section{Hemocyte viability, total hemocyte and sub-population concentrations}

An aliquot of $100 \mu \mathrm{L}$ of pooled hemolymph was transferred into a tube containing a mixture of $200 \mu \mathrm{L}$ anti-aggregant solution for hemocytes (AASH) and $100 \mu \mathrm{L}$ filtered sterile seawater (FSSW). AASH was prepared according to Auffret and Oubella [35]. Hemocyte DNA was stained with two fluorescent DNA/RNA specific dyes, SYBR Green I (final concentration 10X) and propidium iodide (PI, final concentration of $20 \mu \mathrm{g} \cdot \mathrm{mL}^{-1}$ ), in darkness at room temperature for 60 minutes before flow-cytometric analysis. SYBR Green I permeates both dead and live cells, while PI permeates only through membranes of dead cells. SYBR Green fluorescence was measured at 500-530 nm (green) by flow cytometry while PI fluorescence was detected at 550-600 nm (red). Thus, by counting the cells stained by PI and cells stained by SYBR Green, it was possible to estimate the percentage of viable cells in each sample.

All SYBR Green I stained cells were plotted on a FSC (size) - SSC (granularity) cytogram allowing identification of hemocyte sub-populations. Three sub-populations were distinguished according to their size and granularity and termed granulocytes (high FSC and high SSC), hyalinocytes (high FSC and low SSC) and small agranulocytes (low FSC and low SSC). Total and differential hemocyte concentrations are expressed as number of cells per mL.

\section{Phagocytosis assay}

An aliquot of $100 \mu \mathrm{L}$ pooled hemolymph, diluted with $100 \mu \mathrm{l}$ of FSSW, was mixed with $30 \mu \mathrm{L}$ of YG $2.0 \mu \mathrm{m}$ fluoresbrite microspheres, diluted to 2\% in FSSW (Polysciences, Eppelheim, Germany). After 120 minutes of incubation at $18^{\circ} \mathrm{C}$, hemocytes were fixed with $230 \mu \mathrm{L}$ of a $6 \%$ formalin solution and analysed at $500-530 \mathrm{~nm}$ by flow cytometry to detect cells containing fluorescent beads. The percentage of phagocytic cells was estimated by the percentage of hemocytes that had engulfed three beads and more according to Delaporte et al. [26].

\section{Adhesion capacity}

The adhesive capacity of $C$. gigas hemocytes was assessed by modifying the procedure of Choquet et al. [36]. In the present study, live pathogenic bacteria were replaced by the extra-cellular products (ECP) of the Vibrio aestuarianus, previously demonstrated to inhibit adhesive capacity of $C$. gigas hemocytes [37]. Two sub-samples of each hemolymph pool were distributed $(100 \mu \mathrm{L}$ per well) in 24-well microplates. An aliquot of $100 \mu \mathrm{L}$ FSSW was added to the first sub-sample as a control and $100 \mu \mathrm{L}$ ECP suspension

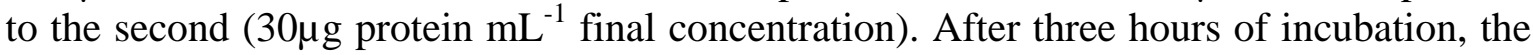
supernatant containing cells not adhering was transferred into a flow cytometer tube and fixed by addition of $200 \mu \mathrm{L}$ of a $6 \%$ formalin solution. After 30 minutes of incubation with SYBR Green I, cell concentration was then evaluated as described above. Since the hemocyte adhesive capacity was measured with or without addition of ECP of Vibrio aestuarianus, results are expressed as the percentage of adhering hemocytes relatively to the initial total hemocyte concentration of the tested pool prior to incubation with or without ECP.

\section{Reactive oxygen species (ROS) production}

Measurement of the ROS production of hemocytes was assayed by modifying the procedure of Lambert et al. [38] using 2'7'-dichlorofluorescein diacetate (DCFH-DA). For this assay, two aliquots of $100 \mu \mathrm{L}$ of hemolymph were diluted with $300 \mu \mathrm{L}$ of FSSW in two flow cytometer tubes. In one of the tubes, $4 \mu \mathrm{L}$ of diphenylene iodonium chloride (DPI, $5 \mu \mathrm{M}$ final concentration), an NADPH-oxidase and NO-synthase inhibitor, was added. 
Subsequently, DCFH-DA (final concentration of $0.01 \mathrm{mM}$ ) was added to each tube previously maintained on ice, and tubes were incubated at $18^{\circ} \mathrm{C}$ for 120 minutes. After the incubation period, DCF fluorescence, quantitatively related to intra-cellular ROS production by hemocytes, was measured at $500-530 \mathrm{~nm}$ by flow cytometry. Results are expressed as the mean fluorescence (in arbitrary units) detected in hemocyte subpopulations maintained in FSSW (basal ROS production) and after addition of DPI (inhibited ROS production).

\section{Statistical analysis}

One or two way analysis of variance (1-way or 2-way ANOVA) were performed for each biochemical and hemocyte parameter using STATGRAPHICS Plus 5.1 statistical software (Manugistics, Inc., Rockville, MD, USA), to test the arachidonic acid dose effect and the time effect after 2 and 4 weeks of conditioning. Percentage data were transformed (arcsin of the square root) before ANOVA or MANOVA, but are presented in figures and tables as untransformed percentage values.

\section{Results}

\section{Condition index and Biochemical composition}

No significant differences between dietary treatments were observed for oyster condition index, oyster tissue dry weight (DW) and carbohydrate, protein and lipid contents over the whole experiment (Table 1, 2-way ANOVA, $\mathrm{p}>0.05$ ). However it can be noted that oyster tissue DW and carbohydrate content were lower at the end of the experiment than initially. Meanwhile, total lipid contents of oysters increased from $0.087 \mathrm{mg} / \mathrm{mg}$ DW initially to an average of $0.110 \mathrm{mg} / \mathrm{mg}$ DW at the end of the experiment (2-way ANOVA, $\mathrm{p}<0.001$ ). Protein content of oysters was stable during the whole experiment.

\section{Fatty acid composition of gill polar lipids}

\section{Impact of the dietary conditioning with with ArA-supplemented T-Iso}

Feeding oysters with T-Iso alone (without ArA supplementation) resulted in an enrichment of gill polar lipids with 18:1n-7, 18:1n-9, 18:2n-6, 18:3n-3, 18:4n-3, 22:6n-3, and a decrease in 20:5n-3 (Table 2). Similar changes were observed in gill polar lipids of oysters fed ArA-supplemented T-Iso (Table 2), but ArA supplementation greatly increased the 20:4n-6 percentage of gill polar lipids as early as 2 weeks into the dietary conditioning period (Table 2, Figure 1). At the end of the experiment, percentages of 20:4n-6 reached $15.3 \%$ and $19.7 \%$ in gill polar lipid of oysters fed, respectively, T-Iso supplemented with 0.25 and $0.41 \mu \mathrm{g} \mathrm{mL}^{-1}$ of ArA solution while it stayed at $6.2 \%$ in those fed T-Iso alone. This high increase in 20:4n-6 also led to a significant decrease in 20:5n-3 and 22:6n-3, a significant increase of total n-6 fatty acid contents in gill polar lipids, and consequently a decrease in the n-3/n-6 ratio and 20:5n-3/20:4n-6 ratio. However, the proportions of the different fatty acid classes (SAFA, MUFA, PUFA) were not affected by the dietary conditioning. 


\section{Impact of conditioning with ArA solution and without algae (control experiment)}

The fatty acid composition of gill polar lipids was also greatly affected by 2 weeks of ArA dietary conditioning with 0.25 and $0.41 \mu \mathrm{g} \mathrm{mL}^{-1}$ of ArA without algae supplementation (Table 3). The percentage of 20:4n-6 of gill polar lipids increased two fold after 2 weeks with ArA supplementation and reached 11.3 and $12.1 \%$ in oysters fed 0.25 and $0.41 \mu \mathrm{g}$ $\mathrm{mL}^{-1}$, respectively. However, no dose effect was recorded. Similarly but at a lesser extent than in the experiment with algae, feeding oysters with 0.25 and $0.41 \mu \mathrm{g} \mathrm{mL} \mathrm{m}^{-1}$ also resulted in a significant decrease of 22:6n-3, a significant increase of total n-6 fatty acids (from 9.8 to 14.5 and $15.5 \%$ respectively) in gill polar lipids, and a significant decrease in $n-3 / n-6$ ratio (from 4.0 to 2.2 and 2.4 respectively) and 20:5n-3/20:4n-6 ratio (from 1.7 to 0.9 and $1.0)$.

\section{Hemocyte parameters}

\section{Hemocyte viability and concentrations}

Hemocyte viability was high and similar for oysters fed T-Iso supplemented with 0.0, 0.25 and $0.41 \mathrm{ArA} \mu \mathrm{g} \mathrm{mL}{ }^{-1}$ (Table 4).

During the experiment, the total hemocyte (including granulocytes, hyalinocytes and agranulocytes) tended to increase in oysters fed T-Iso supplemented with ArA solutions (1way ANOVA, p>0.05). When hemocyte subpopulations were evaluated, it was apparent that granulocyte and hyalinocyte concentrations of oysters fed T-Iso supplemented with 0.25 and $0.41 \mu \mathrm{g} \mathrm{mL}^{-1}$ of ArA solutions tended to be higher than those of oysters fed T-Iso alone (Table 4).

\section{Percentage of phagocytic hemocytes}

After 2 weeks of experimental feeding, the percentage of phagocytic hemocytes from oysters fed T-Iso supplemented with ArA solutions was significantly higher than for oysters fed T-Iso alone (Figure 2, 1-way ANOVA, $\mathrm{p}<0.05$ ); however, was not different anymore from control animals after 4 weeks of dietary conditioning (1-way ANOVA, $\mathrm{p}>0.05)$.

\section{Adhesive capacity}

After 2 and 4 weeks of dietary conditioning, no change in adhesive capacity of hemocytes incubated with FSSW could be seen among the three treatment groups (average of 93\% of adhering cells during the whole experiment, data not shown). However, hemocytes of oysters fed T-Iso alone showed a greater reduction in adhesion in response to ECP than did oysters fed T-Iso supplemented with ArA solutions, but this was not statistically significant (Figure 3).

\section{Reactive oxygen species (ROS) production}

ROS production by granulocytes and hyalinocytes are presented in Figure 4. A significant dietary effect was observed for the basal ROS production of each hemocyte sub-population after 4 weeks of dietary conditioning (1-way ANOVA, $\mathrm{p}<0.05$ ). Granulocytes and hyalinocytes of oysters fed T-Iso supplemented with ArA at 0.25 and $0.41 \mu \mathrm{g} \mathrm{mL}$ generated the highest basal ROS production (average of 360 A.U.). An increase of 160 A.U. for granulocytes and hyalinocytes was observed, when compared to the values obtained with oysters fed T-Iso alone (average of 198 A.U.). Moreover, the basal ROS production increased continuously between the initial sampling and the end of the experiment for hemocytes of oysters fed T-Iso supplemented with ArA solutions, while those of oysters fed T-Iso alone remained quite stable. 
Regarding ROS production after DPI incubation, an inhibition of ROS production was observed for both hemocyte sub-populations with an average of 64.5 and 56 A.U. of DCF fluorescence measured during the whole experiment in granulocytes and hyalinocytes, respectively. No dietary treatment effect was detected for each hemocyte sub-population when incubated with DPI (2-way ANOVA, p>0.05).

\section{Discussion}

\section{Impact of the dietary conditioning on gill fatty acid composition}

Changes measured in the fatty acid composition of hemocyte membranes were shown to be closely related to those in gill membranes in dietary experiments [25]; therefore, in the present study fatty acid analyses were performed on gills rather than on hemocyte samples, which are more difficult to collect in significant amounts.

The observed changes in fatty acid composition of gill polar lipids are in agreement with other studies using T-Iso as a mono-specific diet [26, 39-46]. More noteworthy was the increased incorporation of ArA in gill polar lipids from $4.5 \%$ to $19.7 \%$ for oysters fed 4 weeks T-Iso supplemented with ArA solutions. Such ArA enrichment of polar lipids was also reported by Séguineau et al. [27] using the same technique of supplementation in $C$. gigas oyster spat for 5 weeks. High concentrations of ArA in bivalve phospholipids observed in the present report and in the study of Séguineau et al. [27] have not been previously reported in the literature, whatever the tissue, the development stages and species considered. The highest percentage of ArA in polar lipids lastly found in the literature reached $7.5 \%$ in juveniles of C. gigas and 10\% in Ruditapes philippinarum [26]. Also, our results confirmed that this supplementation technique greatly increased the membrane contents of polyunsaturated fatty acids, such as ArA. Interestingly, direct ArA supplementation without algae performed in this study showed that algal feeding was not necessary to obtain good incorporation of ArA supplied in solution directly into the tanks. Indeed, increases of $40 \%$ and $44 \%$ in the ArA content in gill polar lipids were observed after 2 weeks of conditioning (from $6.8 \%$ to $11.3 \%$ and $12.2 \%$ ). Thus, we can suggest, as proposed by Bunde and Fried [47], that the ArA may be directly incorporated through mantle and gill membranes without passing through the digestive system. However, it must be stressed that ArA solutions were 2-fold more efficiently incorporated when combined with the microalgae than when provided alone. The free ArA added to the rearing tank could be coated to or be incorporated by the algae favouring thus its high incorporation and assimilation in the oyster lipids.

Concomitantly to ArA incorporation, a decrease in n-3 PUFAs, especially EPA content in gills was reported during the dietary experiment resulting in a decrease in the $n-3 / n-6$ and EPA/ArA ratio. Although effect of ArA supplementation on oyster immune parameters may primarily reflect the ArA content increase, the decrease of EPA content and n-3/n-6 ratio may also affect these parameters. Indeed, in vertebrates, changes in $n-3$ and n-6 composition and their ratio are well known to affect immune parameters. For example, EPA by competing with ArA for the eicosanoid production can modulate immune functions $[1,2]$. 


\section{Impact of the arachidonic acid supplementation on immune parameters}

The immune system of bivalves relies on innate defense mechanisms for its response to pathogens. The cellular component of this innate immunity is mediated by hemocytes, which are responsible for recognition, phagocytosis, and elimination of non-self particles [48-50]. For this purpose, they generate a variety of microbicidal products including reactive oxygen species.

In the present study, total and sub-population hemocyte concentrations tended to be higher for oysters fed T-Iso supplemented with ArA. This is in agreement with increased hemocyte concentration observed in the study of Delaporte et al. [26] in oysters and clams fed Chaetoceros calcitrans, which carried the highest amounts of ArA compared to two others algae T-Iso and Tetraselmis suecica. However, in bivalves, it is not clear whether the increase in hemocyte concentration results from production of new cells due to an ArA riched diet effect or migration of cells from deeper tissue into the circulating system. Moreover, comparison of our results with vertebrate immune cell proliferation must be done with caution since in vertebrates this process occurs through the binding of a mitogen to a receptor (adaptive response) which lead to a complex cascade of biochemical events. However, Peres et al. [51] demonstrated that ArA can modulate lymphocyte proliferation of rats according to the concentration of ArA used for loading macrophages and the percentage of macrophage in the co-culture of cells. Concomitantly, in a review, PetersGolden et al. [52] underlined that leukotrienes influence innate immune response by direct effect on leukocyte accumulation, microbial phagocytosis and killing and indirect effects mediated by elaboration of other inflammatory molecules. Consequently, although scarce references concerning eicosanoid production in bivalves exist [53-55], we proposed that changes in fatty acid composition, especially in ArA, may have affected eicosanoid metabolite production which may be implicated in the increased hemocyte concentration observed in the present study in oysters.

With regard to hemocyte functional activities, phagocytosis by hemocytes was significantly affected by the dietary treatments after 2 weeks of conditioning. At this time, the percentage of phagocytic cells of oysters fed T-Iso supplemented with 0.25 and $0.41 \mu \mathrm{g}$ $\mathrm{mL}^{-1}$ of ArA was higher than that of oysters fed T-Iso alone. The highest percentage of phagocytic hemocytes was associated with the highest ArA content of gill polar lipids. The relationship between ArA and phagocytosis observed in this study may be also related to ArA derived eicosanoid metabolites. Indeed, Canesi et al. [56] demonstrated that bacterial killing of hemocytes of mussel Mytilus edulis was reduced by inhibitors of $\mathrm{PLA}_{2}$ and cycloxygenase activities, indicating that eicosanoid production is involved in mediating the response to bacterial challenge. Moreover, ArA metabolites (i.e. prostaglandins) were demonstrated to be involved in the nodulation process of insect hemocytes, which is the predominant response to large bacterial infections and results in the formation of an overlapping sheath of hemocytes around an infection target [57-62]. Several in vitro studies in vertebrates also demonstrated a modulating effect of ArA in the phagocytosis process [3-8]. Meanwhile, Brock et al. [63] demonstrated that $\mathrm{LTB}_{4}$ and $\mathrm{PGE}_{2}$ are successively expressed in macrophages during a time exposition to LPS affecting the subsequent bacterial activity of macrophage when challenged with Klebseilla pneumonia. Therefore, changes in the percentage of phagocytic hemocytes observed over the ArA dietary experiment may be related to subtle changes in the ratio of ArA derived eicosanoids (i.e. LTB4 / PGE2) produced by hemocytes. 
Concomitantly with the increase of phagocytosis, an increase of adhesive capacity of ECP challenged hemocytes from oysters fed T-Iso supplemented with 0.25 and $0.41 \mu \mathrm{g} \mathrm{mL}^{-1}$ of ArA was observed. This result is similar to the study of Mandato et al. [58] and Miller et al. [64], who demonstrated that ArA metabolites are involved in the hemocyte spreading process (similar to the process involved in our adhesive assay) in insects and suggests that eicosanoid products may also be implicated in the adhesive capacity of oyster hemocytes. Interestingly, although the inhibitory effect of ECP on hemocyte adhesive capacity demonstrated by Labreuche et al. [37] was confirmed in this study, ArA supplementation appeared to counteract its effect.

An increase of the basal ROS production by hemocytes was observed at the end of the experiment for oysters fed T-Iso supplemented with ArA solutions. It is important to note that addition of diphenylene iodonium chloride (DPI), an inhibitor of the NADPH-oxidase and of the NO-synthase pathways, strongly decreased the basal ROS production from hemocytes. This allowed us to confirm that the basal ROS production was associated with NADPH-oxidase and /or NO-synthase-like activities. Also, the highest incorporation of ArA content in gill polar lipids of those oysters seemed to be associated with basal ROS production as previously observed with the C. calcitrans dietary conditioning [26]. In an in vitro study, Mazière et al. [65] demonstrated that human fibroblasts incubated with ArA presented higher ROS production without stimulation than control fibroblasts, but also reported an higher content of lipid peroxidation products. Also, in a review, Calder [1] noted that $\mathrm{LTB}_{4}$ (produced from ArA) enhanced ROS production of vertebrate leukocytes. Thus, in our study, the enormous change in ArA content in gill polar lipids may have lead to a an overproduction of ROS by NADPH-oxidase (with or without the production of $\mathrm{LTB}_{4}$ ) and/or an increase of lipid peroxide products as in vertebrates.

\section{Conclusion}

In conclusion, this study demonstrated that supplementation of ArA appeared to enhance hemocyte concentration, phagocytosis activity and basal ROS production, and to reduce susceptibility of hemocyte adhesive capacity to Vibrio aestuarianus. Based on established knowledge on the role of ArA and its metabolites on immune functions in vertebrates and insects, we propose that ArA and/or its metabolites may be also important in immune responses of oysters. However, additional studies are needed and the use of inhibitors of eicosanoid synthesis should help to establish the involvement of these ArA metabolites in oyster immune parameters. Finally, as the level of ArA reported in gill polar lipids at the end of the dietary conditioning attained the highest level ever reported in literature, we wondered if such level of ArA was not above physiologically-normal levels in oysters. New experiments with lower doses of ArA should be done, perhaps in combination with a supply of antioxidants such as vitamin E and /or C.

\section{Acknowledgements}

We are grateful to all co-workers from the Argenton hatchery for taking care of oysters during the experimental conditioning. The authors would like to thank Dr Gary H. Wikfors, NOAA Fisheries, Northeast Fisheries Center (Connecticut, USA) and Dr Fred Markham, Department of Pathology and Microbiology, University of Prince Edward Island (PEI, Canada) for their critical review and helpful advice's to improve the final 
manuscript. This research was a part of the MOREST project supported by a grant from IFREMER, the Région Bretagne, Région Normandie, Région Pays de Loire, Région Poitou-Charente and the Conseil Général du Calvados.

\section{References}

1. Calder, P.C. (2001) N-3 polyunsaturated fatty acids, inflammation and immunity: pouring oil on troubled waters or another fishy tale?, Nut. Res. 21, 309-341.

2. Harbige, L.S. (2003) Fatty acids, the immune response, and autoimmunity: a question of n-6 essentiality and the balance between n-6 and n-3, Lipids 38, 323-341.

3. Borda, E.S., Tenenbaum, A., Sales, M.E., Rumi, L. and Sterin-Borda, L. (1998) Role of arachidonic acid metabolites in the action of a beta- adrenergic agonist on human monocyte phagocytosis, Prostaglandins, Leukotrienes and Essential fatty acids 58, 8590.

4. Bailie, M.B., Standiford, T.J., Laichalk, L.L., Coffey, M.J., Strieter, R. and PetersGolden, M. (1996) Leukotriene-deficient mice manifest enhanced lethality from Klebseilla pneumonia in association with decreased alveolar macrophage phagocytic and bactericidal activities, J. Immunol. 5221-5224,

5. Davidson, J., Kerr, A., Guy, K. and Rotondo, D. (1998) Prostaglandin and fatty acid modulation of Escherichia coli O157 phagocytosis by human monocytic cells, Immunol. 94, 228-234.

6. Lloret, S. and Moreno, J.J. (1996) Role of kinases and G-proteins on arachidonate release induced by zymosan in mouse peritoneal macrophages, Internat. J. Biochem. Cell Biol. 28, 465-472.

7. Mancuso, P., Standiford, T.J., Marshall, T. and Peters-Golden, M. (1998) 5Lipoxygenase reaction products modulate alveolae macrophage phagocytosis of Klebsiella pneumonia, Infection and Immunity. 66, 5140-5146.

8. Lennartz, M.R. (1999) Phospholipases and phagocytosis: the role of phospholipidderived second messengers in phagocytosis, Internat. J. Biochem. Cell. Biol. 31, 415430.

9. Sheldon, W.M.J. and Blazer, V.S. (1991) Influence of dietary lipid and temperature on bactericidal activity of Channel catfish macrophages, J. Aqua. Animal Health. 3, 87-93.

10. Fracalossi, D.M. and Lowell, R.T. (1994) Dietary lipid sources influence responses of channel catfish (Ictalurus punctatus) to challenge with the pathogen Edwardsiella ictaluri, Aquaculture. 98, 363-379.

11. Kiron, V., Fuduka, H., Takeushi, T. and Watanabe, T. (1995) Essential fatty acids nutrition and defense in rainbow trout Oncorhynchus mykiss, Comp. Biochem. Physiol. 111 A, 361-367.

12. Lingenfelser, J.T., Blazer, V.S. and Gay, J. (1995) Influence of fish oils in production catfish feeds on slected disease resistance factors, J. Applied Aquaculture. 5(2), 37-48.

13. Lin, Y.H. and Shiau, S.Y. (2003) Dietary lipid requirement of grouper, Epinephelus malabaricus, and effects on immune responses, Aquaculture. 225, 243-250.

14. Thompson, K.D., Tatner, M.F. and Henderson, R.J. (1996) Effects of dietary (n-3) and (n-6) polyunsaturated fatty acid ratio on the immune response of Atlantic salmon, Salmo salar L., Aquaculture Nut. 2, 21-31.

15. Wu, F.C., Ting, Y.Y. and Chen, H.Y. (2003) Dietary docosahexaenoic acid is more optimal than eicosapentaenoic acid affecting the level of cellular defence responses of the juvenile grouper Epinephelus malabaricus, Fish Shellfish Immunol. 14, 223-238. 
16. Tafalla, C., Figueras, A. and Novoa, B. (2002) Possible role of LTB4 in the antiviral activity of turbot (Scophthalmus maximus) leukocyte-derived supernatants against viral hemorrhagic septicemia virus (VHSV), Develop. Comp. Immunol. 26, 283-293.

17. Wikfors, G.H., Patterson, G.W., Ghosh, P., Lewin, R.A., Smith, B.C. and Alix, J.H. (1996) Growth of post-set oysters, Crassostrea virginica, on high-lipid strains of algal flagellates Tetraselmis spp., Aquaculture. 143, 411-419.

18. Brown, M.R., McCausland, M.A. and Kowalski, K. (1998) The nutritional value of four Australian microalgal strains fed to Pacific oyster Crassostrea gigas spat, Aquaculture. 165, 281-293.

19. Knauer, J. and Southgate, P.C. (1997) Growth and fatty acid composition of Pacific oyster (Crassostrea gigas) spat fed a spray-dried freshwater microalga (Spongiococcum excentricum) and microencapsulated lipids, Aquaculture. 154, 293303.

20. Knuckey, R.M., Brown, M.R., Barrett, S.M. and Hallegraeff, G.M. (2002) Isolation of new nanoplanktonic diatom strains and their evaluation as diets for juvenile Pacific oysters (Crassostrea gigas), Aquaculture. 211, 253-274.

21. McCausland, M.A., Brown, M.R., Barrett, S.M., Diemar, J.A. and Heasman, M.P. (1999) Evaluation of live microalgae and microalgal pastes as supplementary food for juvenile Pacific oysters (Crassostrea gigas), Aquaculture. 174, 323-342.

22. Martinez-Fernandez, E., Acosta-Salmon, H. and Rangel-Davalos, C. (2004) Ingestion and digestion of 10 species of microalgae by winged pearl oyster Pteria sterna (Gould, 1851) larvae, Aquaculture. 230, 417-423.

23. Hendriks, I.E., van Duren, L.A. and Herman, P.M.J. (2003) Effect of dietary polyunsaturated fatty acids on reproductive output and larval growth of bivalves, $J$. Exp. Mar. Biol. Ecol. 296, 199-213.

24. Hégaret, H., Wikfors, G.H., Soudant, P., Delaporte, M., Alix, J.H., Smith, B.C., Dixon, M.S., Quere, C., Le Coz, J.R. and Paillard, C. (2004) Immunological competence of eastern oysters, Crassostrea virginica, fed different microalgal diets and challenged with a temperature elevation, Aquaculture. 234, 541-560.

25. Delaporte, M. (2005) Modulation des paramètres hémocytaires par la nutrition chez l'huître creuse Crassostrea gigas. Implication dans les mortalités estivales. Ph.D. Thesis, University of Rennes 1, Rennes (France), pp. 421.

26. Delaporte, M., Soudant, P., Moal, J., Lambert, C., Quéré, C., Miner, P., Choquet, G., Paillard, C. and Samain, J.-F. (2003) Effect of a mono-specific algal diet on immune functions in two bivalves species Crassostrea gigas and Ruditapes philippinarum, $J$. Exp. Biol. 206, 3053-3064.

27. Séguineau, C., Soudant, P., Moal, J., Delaporte, M., Miner, P., Quéré, C. and Samain, J.F. (2005) Techniques for delivery of Arachidonic acid to Pacific oyster, Crassostrea gigas spat, Lipids. 40, 931-939.

28. Walne, P.R. and Mann, R. (1975) Growth and biochemical composition in Ostrea edulis and Crassostrea gigas, in Ninth European Marine Biology Symposium (Barnes, H., eds), 587-607.

29. Delaporte, M., Soudant, P., Moal, J., Kraffe, E., Marty, Y. and Samain, J.F. (2005) Incorporation and modification of dietary fatty acids in gill polar lipids by two bivalve species Crassostrea gigas and Ruditapes philippinarum, Comp. Biochem. Physiol. 140A, 460-470.

30. Bligh, E.G. and Dyer, W.J. (1959) A rapid method of total lipid extraction and purification., Can. J. Biochem. Physiol. 37, 911-917. 
31. Dubois, M., Gilles, K.A., Hamilton, J.K., Rebers, P.A. and Smith, F. (1956) Colorimetric method for determination of sugars and related substances, Anal. Chem. 28, 350-356.

32. Lowry, O.H., Rosebrough, N.J., Farr, A.L. and Randall, R.J. (1951) Protein measurement with the Folin phenol reagent., J. Biol. Chem. 265-275.

33. Marty, Y., Delaunay, F., Moal, J. and Samain, J.F. (1992) Change in the fatty acid composition of Pecten maximus (L.), J. Exp. Mar. Biol. Ecol. 163, 221-234.

34. Allen, W.V. and Conley, H. (1982) Transport of lipids in the blood of the Pacific oyster, Crassostrea gigas (Thunberg), Comp. Biochem. Physiol. 71B, 201-207.

35. Auffret, M. and Oubella, R., (1995) Cytological and cytometric analysis of bivalves molluscs hemocytes, in Techniques in fish immunology (Stolen, J.S., Fletcher, C., Smith, S.A., Zelikoff, J.T., Kaattari, S.L., Anderson, R.S., Soderhall, K., and WeeksPerkins, B.A, eds.), pp. 55-64, Fair Haven: SOS Publication.

36. Choquet, G., Soudant, P., Lambert, C., Nicolas, J.L. and Paillard, C. (2003) Reduction of adhesion properties on Ruditapes philippinarum hemocytes exposed to Vibrio tapetis, Dis. Aquat. Org. 57, 109-116.

37. Labreuche, Y., Soudant, P., Goncalves, M., Lambert, C. and Nicolas, J.L. (2006) In vitro effects of extracellular products (ECPs) from the pathogenic Vibrio aestuarianus strain 01/32 on the oyster Crassostrea gigas cellular immune responses, Develop. Comp. Immunol. 30, 367-379.

38. Lambert, C., Soudant, P., Choquet, G. and Paillard, C. (2003) Measurement of Crassostrea gigas hemocyte oxidative metabolism by flow cytometry. A tool to evaluate pathogenic Vibrio inhibiting capacity., Fish Shellfish Immunol. 15, 225-240.

39. Berntsson, K.M., Jonsson, P.R., Wängberg, S.A. and Carlsson, A.S. (1997) Effects of broodstock diets on fatty acid composition, survival and growth rates in larvae of the European flat oyster, Ostrea edulis, Aquaculture. 154, 139-153.

40. Delaunay, F., Marty, Y., Moal, J. and Samain, J.F. (1992) Growth and lipid class composition of Pecten maximus (L.) larvae grown under hatchery conditions, J. Exp. Mar. Biol. Ecol. 163, 209-219.

41. Langdon, C.J. and Waldock, M.J. (1981) The effect of algal and artificial diets on the growth and fatty acid composition of Crassostrea gigas spat., J. Mar. Biol. Assoc. U.K.. 61, 431-448.

42. Fernandez-Reiriz, M.J., Labarta, U., Albentosa, M. and Perez-camacho, A. (1998) Effect of microalgal diets and commercial wheatgerm flours on the lipid profile of Ruditapes decussatus spat, Comp. Biochem. Physiol. 124B, 369-377.

43. Fernandez-Reiriz, M.J., Labarta, U., Albentosa, M. and Perez-Camacho, A. (1999) Lipid profile and growth of the clam spat, Ruditapes decussatus (L), fed with microalgal diets and cornstarch, Comp. Biochem. Physiol. 124B, 309-318.

44. Soudant, P., Marty, Y., Moal, J., Robert, R., Quéré, C., Le Coz, J.R. and Samain, J.F. (1996) Effect of food fatty acid and sterol quality on Pecten maximus gonad composition and reproduction process, Aquaculture. 143, 361-378.

45. Soudant, P., Moal, J., Marty, Y. and Samain, J.F. (1997) Composition of polar lipid classes in male gonads of Pecten maximus (L.). Effect of nutrition, J. Exp. Mar. Biol. Ecol. 215, 103-114.

46. Soudant, P., Van Ryckeghem, K., Marty, Y., Moal, J., Samain, J.F. and Sorgeloos, P. (1999) Comparison of the lipid class and fatty acid composition between a reproductive cycle in nature and a standard hatchery conditioning of the Pacific Oyster Crassostrea gigas, Comp. Biochem. Physiol. 123B, 209-222. 
47. Bunde, T.A. and Fried, M. (1978) The uptake of dissolved free fatty acids from seawater by a marine filter feeder, Crassostrea virginica, Comp. Biochem. Physiol. 60A, 139-144.

48. Cheng, T.C., (1996) Hemocytes : forms and functions, in The eastern oyster Crassostrea virginica (Newell, R.I.E., Kennedy, V.S.and Eble, A.F., eds.), pp. 299329, Maryland Sea Grant College.

49. Chu, F.L.E., (2000) Defense Mechanims of Marine Bivalves, in Recent advances in marine biotechnology. Immunology and Pathology. (Fingerman M, N., and Nagabhushanam, R., eds.), pp. 1-42, Enfield, NH, Plymouth, UK: Sciences publishers.

50. Pipe, R.K. (1992) Generation of reactive oxygen metabolites by the haemocytes of the mussel Mytilus edulis, Develop. Comp. Immunol. 16, 111-122.

51. Peres, C.M., Otton, R. and Curi, R. (2005) Modulation of lymphocyte proliferation by macrophages and macrophages loaded with arachidonic acid, Cell Biochem. Funct. 23, 373-381.

52. Peters-Golden M, C.C., Mancuso P., and Cofrey, M.J. (2004) Leukotrienes: Underappreciated mediators of innate immune responses, J. Immunol. 173, 589-594.

53. Ruggeri, B.A. and Thoroughgood, C.A. (1985) The identification of several prostaglandin moieties in Crassostrea virginica and Mytilus edulis by radioimmunoassay and high performance liquid chromatography, Prostagland. Leukotrienes Med. 20, 69-77.

54. Saintsing, D.G., Hwang, D.H. and Dietz, T.H. (1983) Production of prostaglandins E2 and F2? in the freshwater mussel Ligumia subrostrata: Relation to sodium transport, $J$. Pharm. Exp. Ther. 226, 455-461.

55. Osada, M. and Nomura, T. (1990) The levels of prostaglandins associated with the reproductive cycle of the scallop, Patinopecten yessoensis, Prostaglandins. 40, 229239.

56. Canesi, L., Scarpato, A., Betti, M., Ciacci, C., Pruzzo, C. and Gallo, G. (2002) Bacterial killing by mytilus hemocyte monolayers as a model for investigating the signaling pathways involved in mussel immune defence, Mar. Environ. Res. 54, 547551.

57. Dean, P., Gadsden, J.C., Richards, E.H., Edwards, J.P., Keith Charnley, A. and Reynolds, S.E. (2002) Modulation by eicosanoid biosynthesis inhibitors of immune responses by the insect Manduca sexta to the pathogenic fungus Metarhizium anisopliae, J. Invertebr. Pathol. 79, 93-101.

58. Mandato, C.A., Diehl-Jones, W.L., Moore, S.J. and Downer, R.G.H. (1997) The effects of eicosanoid biosynthesis inhibitors on prophenoloxidase activation, phagocytosis and cell spreading in Galleria mellonella, J. Insect. Physiol. 43, 1-8.

59. Stanley-Samuelson, D.W. and Pedibhotla, V.K. (1996) What can we learn from prostaglandins and related eicosanoids in insects?, Insect Biochem. Mol. Biol. 26, 223234.

60. Stanley-Samuelson, D.W., Pedibhotla, V.K., Rana, R.L., Rahim, N.A.A., Hoback, W.W. and Miller, J.S. (1997) Eicosanoids mediate nodulation responses to bacterial infections in larvae of the silkmoth, Bombyx mori, Comp. Biochem. Physiol. 118 A, 93100.

61. Lavine, M.D. and Strand, M.R. (2002) Insect hemocytes and their role in immunity, Insect Biochem. Mol. Biol. 32, 1295-1309.

62. Tunaz, H., Park, Y., Buyukguzel, K., Bedick, J.C., Aliza, A.R. and Stanley, D.W. (2003) Eicosanoids in insect immunity: bacterial infection stimulates hemocytic phospholipase A2 activity in Tobacco hornworms, Arch. Insect Biochem. Physiol. 52, $1-6$. 
63. Brock, T.G., McNish, R.W., Mancuso, P., Coffey, M.J. and Peters-Golden, M. (2003) Prolonged lipopolysaccharide inhibits leukotriene synthesis in peritoneal macrophages: mediation by nitric oxide and prostaglandins, Prostaglandins and Other Lipid Mediators. 71, 131-145.

64. Miller, J.S. (2005) Eicosanoids influence in vitro elongation of plasmatocytes from the tabacco hornworm, Manduca sexta, Arch. Insect Biochem. Physiol. 59, 42-51.

65. Mazière, C., Conte, M.A., Degonville, J., Ali, D. and Mazière, J.C. (1999) Cellular enrichment with polyunsaturated fatty acids induces an oxidative stress and activates the transcription factors AP1 and $\mathrm{NF}_{\mathrm{k}} \mathrm{B}$, Biochem. Biophys. Res. Commun. 265, 116122. 
Table 1: Condition index ( $n=15$, Mean \pm SD), oyster tissue dry weight in grams ( $n=15$, Mean \pm SD) and carbohydrate, lipid and protein contents expressed in mg per mg oyster dry weight ( $\mathrm{n}=3$ pools of 5 oysters, Mean $\pm \mathrm{SD}$ ) of oysters fed T-Iso supplemented with $0,0.25$ and $0.41 \mu \mathrm{g} \mathrm{mL}^{-1}$ of ArA. Asterisks indicate significant difference with initial composition (T-test, $\mathrm{p}<0.05$ ).

\begin{tabular}{|c|c|c|c|c|}
\hline & \multirow[t]{2}{*}{ Initial } & \multicolumn{3}{|c|}{ After 4 weeks of conditioning } \\
\hline & & $0 \mu g$ ArA mL $L^{-1}$ & $0.25 \mu \mathrm{g}$ ArA mL $\mathrm{mL}^{-1}$ & $0.41 \mu g$ ArA mL ${ }^{-1}$ \\
\hline Condition index & $4.3 \pm 0.9$ & $3.6 \pm 0.7$ & $3.9 \pm 0.5$ & $3.5 \pm 0.6$ \\
\hline Oyster dry weight & $0.476 \pm 0.17$ & $0.341 \pm 0.07^{*}$ & $0.341 \pm 0.15^{*}$ & $0.302 \pm 0.09^{*}$ \\
\hline Carbohydrate content & $0.205 \pm 0.02$ & $0.160 \pm 0.02^{*}$ & $0.155 \pm 0.01^{*}$ & $0.151 \pm 0.02^{*}$ \\
\hline Lipid content & $0.087 \pm 0.00$ & $0.115 \pm 0.01^{*}$ & $0.109 \pm 0.01^{*}$ & $0.107 \pm 0.00^{*}$ \\
\hline Protein content & $0.359 \pm 0.03$ & $0.403 \pm 0.01$ & $0.380 \pm 0.02$ & $0.393 \pm 0.02$ \\
\hline
\end{tabular}


Table 2: Fatty acid composition of the gill polar lipids, expressed as weight percentage of total fatty acids in the fraction, and total FAs, expressed as $\mu \mathrm{g}$ of FAs per mg of gill wet weight of $C$. gigas fed T-Iso supplemented 0, 0.25 and $0.41 \mu \mathrm{g} \mathrm{mL}{ }^{-1}$ of ArA. Different lower-case letters indicate significant differences between dietary treatments (1-way ANOVA, $\mathrm{p}<0.05)$. Asterisks indicate significant difference with initial composition $(\mathrm{T}$ test, $\mathrm{p}<0.05)$.

initial $\quad$ After 2 weeks of conditioning

After 4 weeks of conditioning

$0 \mu \mathrm{g}$ ArA mL ${ }^{-1} 0.25 \mu \mathrm{g} \operatorname{ArA~mL}^{-1} 0.41 \mu \mathrm{g} \operatorname{ArA~mL}^{-1} 0 \mu \mathrm{g} \mathrm{ArA} \mathrm{mL} L^{-1} 0.25 \mu g \operatorname{ArA~mL}^{-1} 0.41 \mu g \operatorname{ArA~mL}^{-1}$

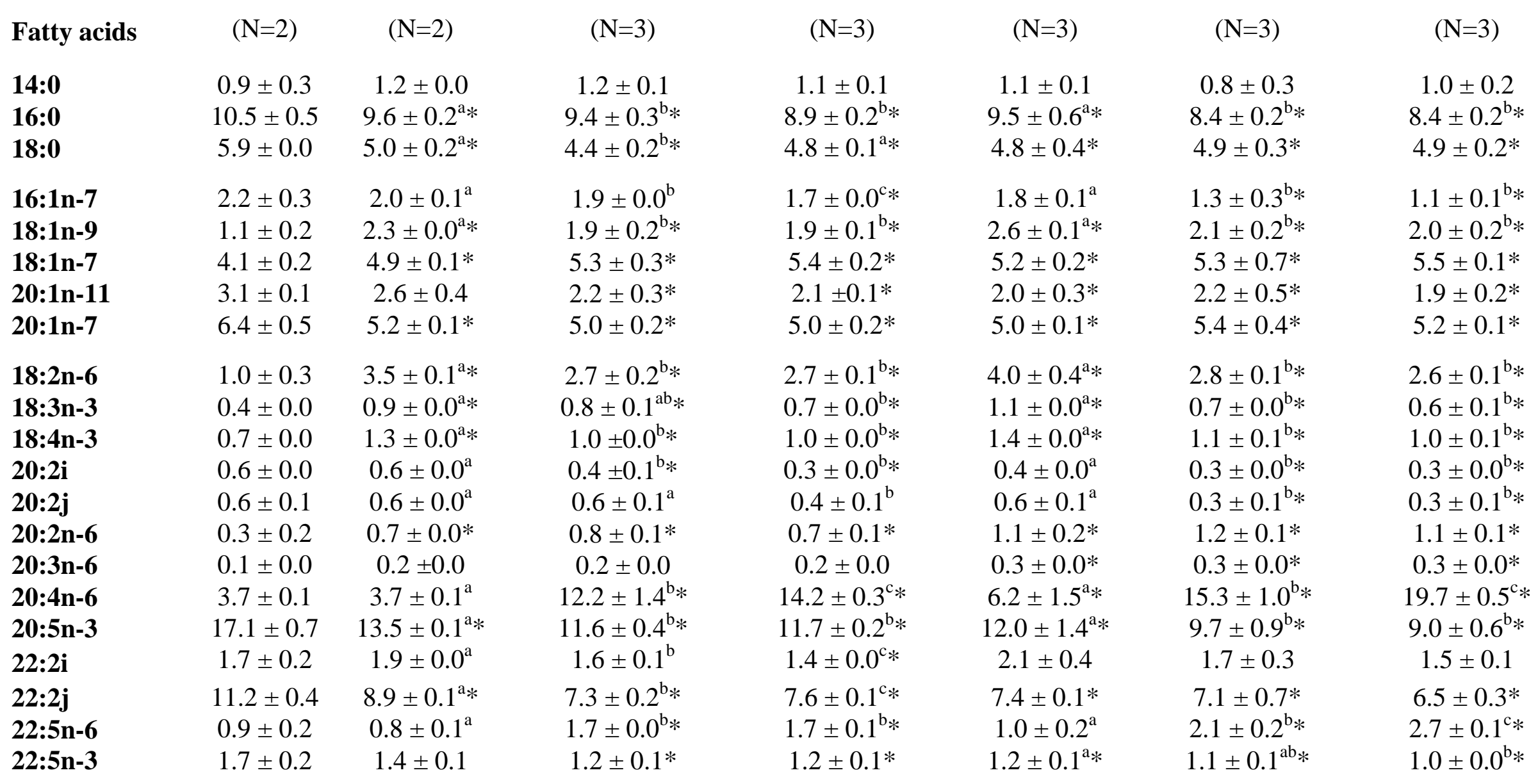




\begin{tabular}{|c|c|c|c|c|c|c|c|}
\hline $22: 6 n-3$ & $17.5 \pm 0.5$ & $21.2 \pm 0.5^{\mathrm{a} *}$ & $18.4 \pm 0.7^{\mathrm{b}}$ & $17.2 \pm 0.4^{\mathrm{c}}$ & $21.3 \pm 0.3^{\mathrm{a}} *$ & $17.2 \pm 1.0^{\mathrm{b}}$ & $15.5 \pm 0.8^{\mathrm{C} *}$ \\
\hline Total SAFA & $19.8 \pm 0.8$ & $18.2 \pm 0.4^{\mathrm{a} *}$ & $16.9 \pm 0.4^{\mathrm{b} *}$ & $17.2 \pm 0.2^{\mathrm{b}_{*}}$ & $17.4 \pm 1.3^{*}$ & $16.1 \pm 0.7^{*}$ & $16.4 \pm 0.6^{*}$ \\
\hline Total MUFA & $19.7 \pm 0.4$ & $19.9 \pm 0.1^{\mathrm{a}}$ & $19.0 \pm 0.2^{\mathrm{b}}$ & $18.8 \pm 0.3^{b}$ & $19.6 \pm 0.1^{\mathrm{a}}$ & $19.8 \pm 0.5^{\mathrm{a}}$ & $18.7 \pm 0.4^{b}$ \\
\hline Total PUFA & $60.5 \pm 1.3$ & $61.8 \pm 0.4^{\mathrm{a}}$ & $63.7 \pm 0.8^{\mathrm{b}} *$ & $64.2 \pm 0.5^{b_{*}}$ & $62.9 \pm 1.1^{*}$ & $64.0 \pm 1.1^{*}$ & $64.8 \pm 0.9 *$ \\
\hline Total n-6 & $7.1 \pm 0.4$ & $9.5 \pm 0.2^{\mathrm{a} *}$ & $18.8 \pm 1.4^{\mathrm{b} *}$ & $21.3 \pm 1.0^{\mathrm{b}_{*}}$ & $13.4 \pm 2.3^{\mathrm{a}}$ & $23.0 \pm 2.0^{\mathrm{b}} *$ & $27.1 \pm 0.2^{\mathrm{C} *}$ \\
\hline Total n-3 & $38.9 \pm 1.4$ & $39.8 \pm 0.2^{\mathrm{a}}$ & $34.4 \pm 0.7^{\mathrm{b} *}$ & $33.0 \pm 0.4^{\mathrm{C}_{*}}$ & $38.6 \pm 1.0^{\mathrm{a}}$ & $31.4 \pm 2.0^{\mathrm{b}} *$ & $28.7 \pm 1.2^{b_{*}}$ \\
\hline Total NMIs & $14.1 \pm 0.3$ & $11.9 \pm 0.1^{\mathrm{a} *}$ & $10.2 \pm 0.1^{\mathrm{b} *}$ & $9.5 \pm 0.3^{\mathrm{C} *}$ & $10.5 \pm 0.1^{\mathrm{a} *}$ & $9.4 \pm 1.0^{\mathrm{b} *}$ & $8.6 \pm 0.3^{\mathrm{b}} *$ \\
\hline$n-3 / n-6$ & $5.5 \pm 0.5$ & $4.2 \pm 0.1^{\mathrm{a} *}$ & $1.8 \pm 0.2^{\mathrm{b}} *$ & $1.6 \pm 0.1^{\mathrm{b} *}$ & $2.9 \pm 0.6^{\mathrm{a} *}$ & $1.4 \pm 0.2^{\mathrm{b}}$ & $1.1 \pm 0.0^{\mathrm{b}}$ \\
\hline $20: 5 n-3 / 20: 4 n-6$ & $4.6 \pm 0.1$ & $3.7 \pm 0.1^{\mathrm{a} *}$ & $1.0 \pm 0.1^{\mathrm{b} *}$ & $0.8 \pm 0.0^{C_{*}}$ & $2.4 \pm 0.8^{\mathrm{a}} *$ & $0.6 \pm 0.1^{b}$ & $0.5 \pm 0.0^{\mathrm{c}}$ \\
\hline $\begin{array}{l}\text { Total FAs } \\
(\mu \mathrm{g} / \mathrm{g} \text { gill } \mathrm{WW})\end{array}$ & $6.3 \pm 0.3$ & $6.3 \pm 0.8$ & $7.1 \pm 0.4$ & $7.6 \pm 0.2$ & $7.5 \pm 0.2$ & $7.2 \pm 0.7$ & $7.3 \pm 0.5$ \\
\hline
\end{tabular}

Note: NMIs= Non Methylene Interrupted Fatty Acids; 20:2i=20:2 $\Delta 5,11 ; 22: 2 \mathrm{i}=22: 2 \Delta 7,13 ; 20: 2 \mathrm{i}=20: 2 \Delta 5,13 ; 22: 2 \mathrm{j}=22: 2 \Delta 7,15 ;$ WW: wet weight 
Table 3: 20:4n-6 content and main FAs classes of the gill polar lipids, expressed as weight percentage of total fatty acids of the fraction, and total FAs, expressed as $\mu \mathrm{g}$ of FAs per mg of gill wet weight of $C$. gigas fed different doses of ArA without algae. Different lower-case letters indicate significant differences between dietary treatments (1-way ANOVA, $\mathrm{p}<0.05)$. Asterisks indicate significant difference with initial composition (T-test, $\mathrm{p}<0.05$ ).

\begin{tabular}{|c|c|c|c|c|}
\hline & \multirow[t]{2}{*}{ Initial } & \multicolumn{3}{|c|}{ After 2 weeks of conditioning } \\
\hline & & $0 \mu g$ ArA mL $\mathrm{mL}^{-1}$ & $0.25 \mu g \operatorname{ArA~mL}{ }^{-1}$ & $0.41 \mu g \operatorname{ArA~mL} L^{-1}$ \\
\hline Fatty acids & $(\mathrm{N}=3)$ & $(\mathrm{N}=3)$ & $(\mathrm{N}=3)$ & $(\mathrm{N}=2)$ \\
\hline $20: 4 n-6$ & $6.8 \pm 0.3$ & $6.7 \pm 0.1^{\mathrm{a}}$ & $11.3 \pm 0.8^{\mathrm{b}_{*}}$ & $12.1 \pm 1.2^{b_{*}}$ \\
\hline $20: 5 n-3$ & $11.2 \pm 0.2$ & $11.5 \pm 0.2$ & $10.9 \pm 1.0$ & $10.4 \pm 0.5$ \\
\hline $22: 6 n-3$ & $24.0 \pm 0.4$ & $22.2 \pm 0.6^{\mathrm{a} *}$ & $19.9 \pm 0.2^{\mathrm{b} *}$ & $19.9 \pm 0.3^{\mathrm{b}} *$ \\
\hline Total SAFA & $16.7 \pm 0.5$ & $17.1 \pm 0.5$ & $17.1 \pm 0.2$ & $17.5 \pm 1.1$ \\
\hline Total MUFA & $21.9 \pm 0.6$ & $21.9 \pm 0.1$ & $20.9 \pm 0.2^{*}$ & $20.5 \pm 0.1^{*}$ \\
\hline Total PUFA & $61.3 \pm 0.2$ & $61.0 \pm 0.4$ & $62.0 \pm 0.0 *$ & $62.0 \pm 1.2$ \\
\hline Total n-6 & $9.8 \pm 0.3$ & $9.7 \pm 0.0^{\mathrm{a}}$ & $14.5 \pm 0.9^{b_{*}}$ & $15.5 \pm 1.4^{\mathrm{b} *}$ \\
\hline Total n-3 & $38.9 \pm 0.3$ & $37.2 \pm 0.4^{\mathrm{a} *}$ & $34.4 \pm 0.9^{\mathrm{b}} *$ & $33.7 \pm 0.3^{\mathrm{b} *}$ \\
\hline$n-3 / n-6$ & $4.0 \pm 0.1$ & $3.8 \pm 0.0^{\mathrm{a}}$ & $2.4 \pm 0.2^{\mathrm{b} *}$ & $2.2 \pm 0.2^{\mathrm{b} *}$ \\
\hline $20: 5 n-3 / 20: 4 n-6$ & $1.7 \pm 0.1$ & $1.7 \pm 0.1^{\mathrm{a}}$ & $1.0 \pm 0.2^{\mathrm{b} *}$ & $0.9 \pm 0.1^{\mathrm{b} *}$ \\
\hline $\begin{array}{l}\text { Total FAs } \\
(\mu g / g \text { gill } W W)\end{array}$ & $5.5 \pm 0.1$ & $4.8 \pm 0.8^{\mathrm{a}}$ & $6.1 \pm 0.5^{b}$ & $6.0 \pm 0.3^{b}$ \\
\hline
\end{tabular}

Note: WW=wet weight 
Table 4: Total and differential hemocyte concentrations and percentage of viable cells in oysters fed T-Iso supplemented with $0,0.25$ and $0.41 \mu \mathrm{g}$ $\mathrm{mL}^{-1}$ of ArA. ( $\mathrm{n}=3$, Mean $\pm \mathrm{SD}$ ). Different lower-case letters indicate significant difference between dietary treatments (1-way ANOVA, $\mathrm{p}<0.05$ ). Asterisks indicate significant difference with initial composition ( $T$-test, $\mathrm{p}<0.05$ ).

\begin{tabular}{|c|c|c|c|c|c|c|c|}
\hline & \multirow[t]{2}{*}{ Initial } & \multicolumn{3}{|c|}{ After 2 weeks of conditioning } & \multicolumn{3}{|c|}{ After 4 weeks of conditioning } \\
\hline & & $0 \mu g \operatorname{ArA~mL} L^{-1}$ & $0.25 \mu \mathrm{g}$ ArA mL $\mathrm{m}^{-1}$ & $0.41 \mu g \operatorname{ArA~mL} L^{-1}$ & $0 \mu \mathrm{g}$ ArA mL $\mathrm{mL}^{-1}$ & $0.25 \mu \mathrm{g}$ ArA mL $\mathrm{mL}^{-1}$ & $0.41 \mu g \operatorname{ArA~mL}^{-1}$ \\
\hline $\begin{array}{c}\text { Total hemocyte counts : } \\
\left({\left.\mathrm{X} 10^{5} \text { cell } \mathrm{mL}^{-1}\right)}\right.\end{array}$ & $4.3 \pm 0.6$ & $4.3 \pm 0.7$ & $5.7 \pm 1.1$ & $6.1 \pm 0.6^{*}$ & $4.4 \pm 1.5$ & $5.8 \pm 1.5$ & $6.0 \pm 1.1$ \\
\hline Granulocytes & $0.3 \pm 0.1$ & $0.5 \pm 0.2$ & $0.7 \pm 0.2^{*}$ & $1.3 \pm 0.0^{*}$ & $0.6 \pm 0.2$ & $1.0 \pm 0.3^{*}$ & $1.1 \pm 0.2^{*}$ \\
\hline Hyalinocytes & $2.2 \pm 0.3$ & $2.6 \pm 0.4$ & $3.8 \pm 0.8^{*}$ & $3.6 \pm 0.8^{*}$ & $3.1 \pm 1.1$ & $3.7 \pm 0.8^{*}$ & $3.9 \pm 1.2^{*}$ \\
\hline Agranulocytes & $1.7 \pm 0.4$ & $1.1 \pm 0.2$ & $1.2 \pm 0.1$ & $1.1 \pm 0.2^{*}$ & $0.7 \pm 0.1^{*}$ & $1.1 \pm 0.7$ & $1.0 \pm 0.2^{*}$ \\
\hline
\end{tabular}




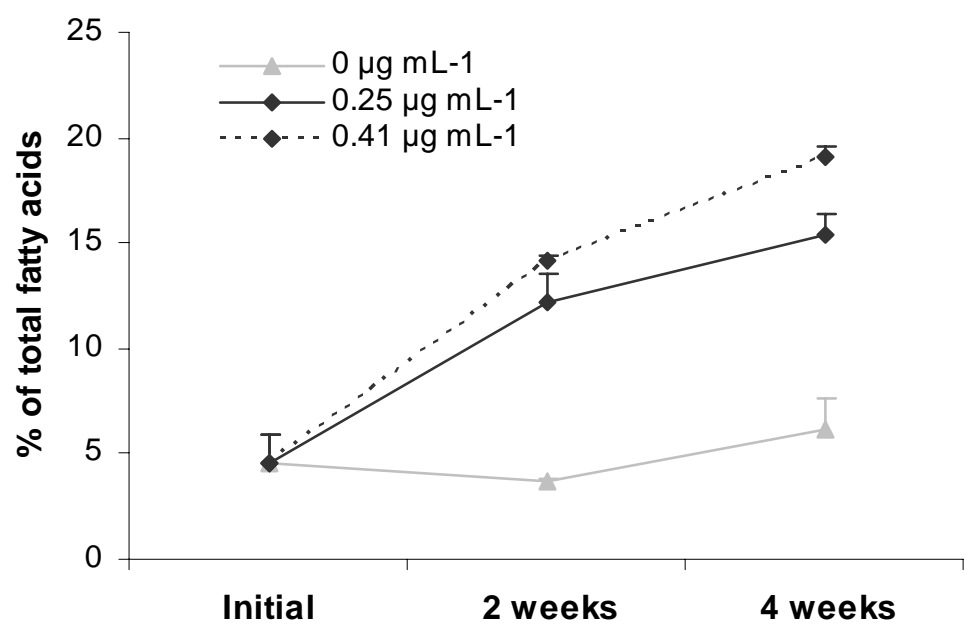

Figure 1: ArA weight percentage of $C$. gigas gill polar lipids during the dietary conditioning (T-Iso supplemented with $0,0.25 \mu \mathrm{g} \mathrm{mL}^{-1}$ and $0.41 \mu \mathrm{g} \mathrm{mL} \mathrm{m}^{-1}$ of ArA).

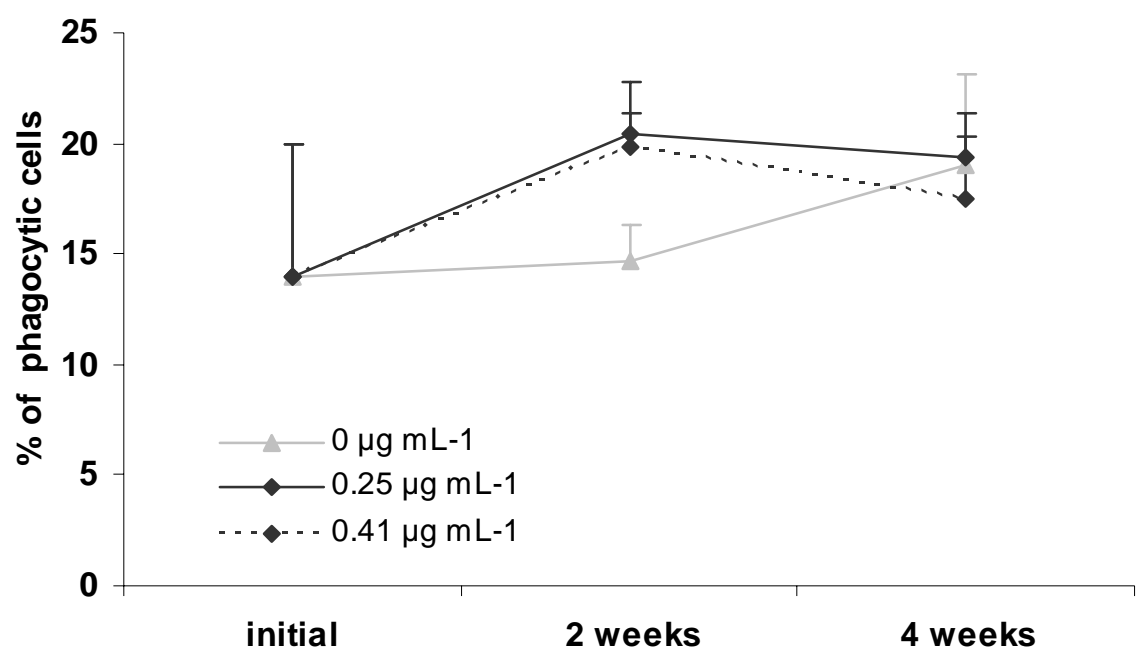

Figure 2: Percentage of phagocytic hemocytes of C. gigas fed T-Iso supplemented with 0 , 0.25 and $0.41 \mu \mathrm{g} \mathrm{mL}{ }^{-1}$ of ArA.

Figure 2 


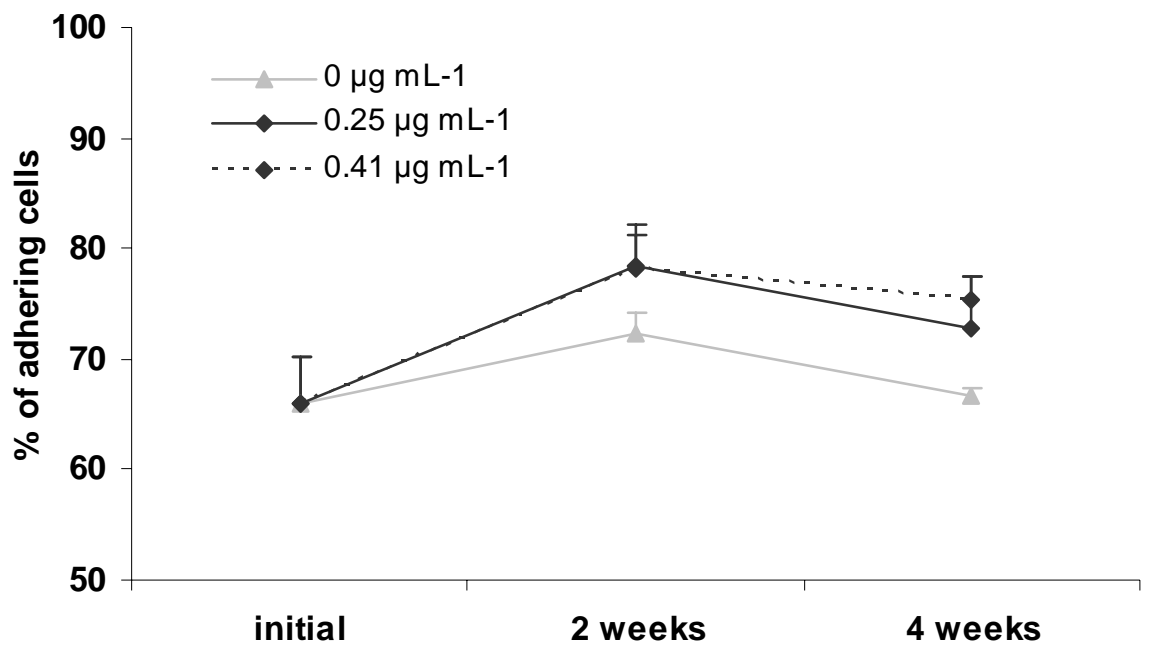

Figure 3: Percentage of adhering cells after three hours of incubation with $30 \mu \mathrm{gL}^{-1}$ of Vibrio aestuarianus extra cellular products (ECP) prepared in sea water. 
A

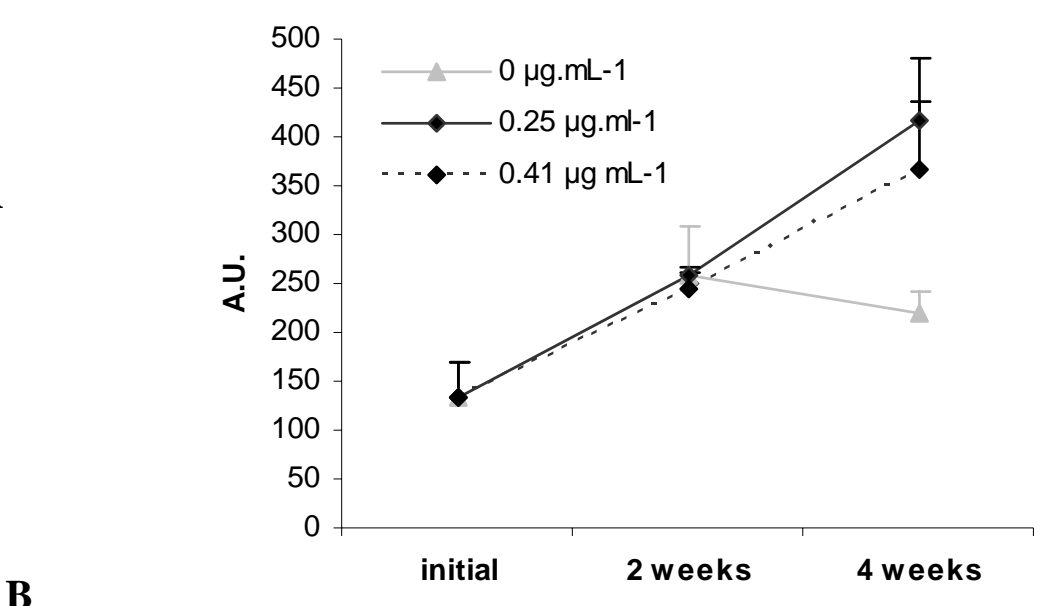

B

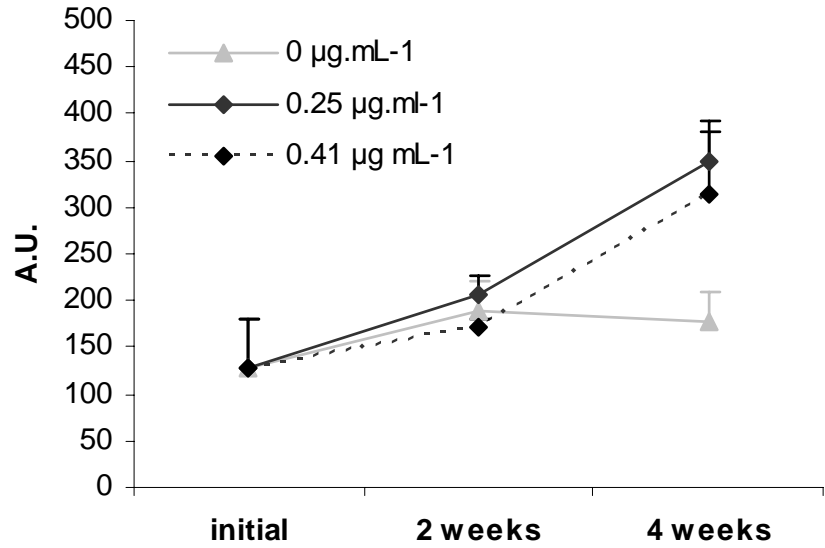

Figure 4 : Reactive oxygen species production of granulocytes (A) and hyalinocytes (B) of oysters fed T-Iso supplemented with $0,0.25$ and $0.41 \mu \mathrm{g} \mathrm{mL}{ }^{-1}$ of ArA. Hemocytes were incubated 2 hours with DCFH-DA in sterile sea water. Results are expressed in Arbitrary Units (A.U.). 